\title{
Macronutrients and heavy metals contents in the leaves of trees from the devastated lands at Kryvyi Rih District (Central Ukraine)
}

\author{
Yuliia Bielyk $^{1, *}$, Vasyl Savosko ${ }^{2}$, Yuriy Lykholat ${ }^{1}$, Hermann Heilmeier ${ }^{3}$, and Ivan Grygoryuk $^{4}$ \\ ${ }^{1}$ Oles Honchar Dnipro National University, Dnipro, 49000, Ukraine \\ ${ }^{2}$ Kryvyi Rih State Pedagogical University, Kryvyi Rih, 50086, Ukraine \\ ${ }^{3}$ Freiberg Mining Academy and University of Technology, 09599, Freiberg, Germany \\ ${ }^{4}$ National University of Life and Environmental Sciences of Ukraine, Kyiv, 03041, Ukraine
}

\begin{abstract}
This research was performed at Petrovsky waste rock dump, the Central part of the Kryvyi Rih iron-ore \& metallurgical district (Dnipropetrovsk region, Ukraine). The macronutrients ( $\mathrm{K}, \mathrm{Ca}, \mathrm{Mg}, \mathrm{P}$ and $\mathrm{S}$ ) and heavy metals ( $\mathrm{Fe}, \mathrm{Mn}, \mathrm{Zn}, \mathrm{Cu}, \mathrm{Pb}$ and $\mathrm{Cd}$ ) contents in the leaves of three species of the trees (Ash-leaved maple, Silver Birch and Black locust) that were collected on devastated lands were assessed. It was established that trees which grow on the Petrovsky dump take place under evident shortage of nutrients (especially $\mathrm{K}$ and $\mathrm{P}$ ) and excess of metals (especially Fe, Mn and $\mathrm{Zn}$ ). It is revealed that Ash-leaved maple and Black locust are more resistant to the geochemical conditions of devastated lands. In this regard, these species of trees can be recommended for forest restoration \& reforestation on devastated lands.
\end{abstract}

\section{Introduction}

Devastated lands, formed as a result of human activity, occupy vast areas: more than 2,000,000 ha worldwide, about 200,000 ha in Ukraine and about 100,000 ha in Germany $[14,16,21]$. These lands are as pollution sources for the atmosphere, soil, surface water. They are also sources of distribution of weeds [7, 22, 23]. Therefore, devastated lands pose a serious threat to human well-being. Currently, planting trees is the most promising way of restoring devastated lands [1, 19]. However, on these lands the ecological conditions are very strict for trees $[7,21,18,22,31]$. Therefore, investigation of chemical composition of trees that naturally grow on devastated lands is very important.

The object of this work: to carry out a comparative analysis of macro nutrients and heavy metals contents in the leaves of trees spontaneously sprouting on the devastated lands at the Kryvyi Rih District.

\section{Materials and methods}

The results of the studies, which were carried out at Petrovsky waste rock dump (Fig. 1) in Central part of the Kryvyi Rih District (Dnipropetrovsk region, Ukraine), were used as the materials for this paper.

Petrovsky waste rock dump was formed for storage: 1) low-prospective iron ores, 2) quartzites 3) shales 4) loose rocks (clay, sand and loam). On this dump the ecological conditions for growth and development of woody plants are typical for Kryvyi Rih region [7]. It is based on the structure of mine rocks, dump's age (about
50 years) and dump's area (26 ha). Territories located for $30 \mathrm{~km}$ apart from industrial facilities and stationed in Gurovsky forest were used as control site.

Sampling of leaves from three species (Ash-leaved Maple Acer negundo L., Silver Birch Betula pendula Roth. and Black Locust Robinia pseudoacacia L.), drying and grinding of them were performed in the fall of 2019 by classical methods $[5,10,11,24]$.

For the sample preparation, to the leaf sample weight of $100 \mathrm{mg} 0.2 \mathrm{ml}$ of $\mathrm{H}_{2} \mathrm{O}$ DI and $1.6 \mathrm{ml}$ of $\mathrm{HNO}_{3}(65 \%)$ were added. The solution was incubated at room temperature during 24 hours. Then, $0.6 \mathrm{ml}$ of HF (4.8\%) and $0.9 \mathrm{ml}$ of $\mathrm{HCl}(36 \%)$ were added to this solution. Subsequently, the solution was placed in the microwave oven (Mikrowellen-Laborsystem, MLS-ETHOS plus). The microwave exposure was continued during 2 hours. Next, $\mathrm{H}_{2} \mathrm{O}$ DI was poured into, diluting the volume of solution to $10 \mathrm{ml}$. Finally, $0.1 \mathrm{ml}$ of Internal Standart was poured to $1 \mathrm{ml}$ of mineralizate collected, after which $\mathrm{H}_{2} \mathrm{O}$ DI was poured again diluting the volume to $10 \mathrm{ml}$.

The final determination of macronutrients $(\mathrm{K}, \mathrm{Ca}, \mathrm{Mg}$, $\mathrm{P}, \mathrm{S})$ and heavy metals ( $\mathrm{Fe}, \mathrm{Mn}, \mathrm{Zn}, \mathrm{Cu}, \mathrm{Pb}, \mathrm{Cd}$ ) concentrations was performed using the Inductively Coupled Plasma Mass Spectrometry (ICP-MS X-Series instrument 2, Thermo Fisher Scientific, USA).

The analytical part of our research was performed on laboratory base of the Institute of Biosciences, Freiberg Mining Academy and University of Technology (Freiberg, Germany).

The obtained results of macronutrients and heavy metals content in the leaves of trees were calculated in $\mathrm{mg} * \mathrm{~kg}^{-1}$ of dry weight $\left(\mathrm{mg}^{*} \mathrm{~kg}^{-1}\right.$ d.w.). Then the results were processed by standard methods of variational

* Corresponding author: belik.uliya@gmail.com 
statistics at the significance level of $p<0,05$ [17].

\section{Results}

\subsection{Macronutrients and heavy metals content in leaves at a control site}

According to scientific literature $[6,8,9]$ the Potassium average content in plants is in the range from 7500 to $15000 \mathrm{mg}^{*} \mathrm{~kg}^{-1}$ d.w. We found that in a control site the values Potassium concentration in the leaves of Birch and Black locusts leaves were below these this range. While, in the maple leaves Potassium concentrations were appeared to be within this range (Table 1). The average Calcium concentrations in plants are from 12500 to $18000 \mathrm{mg}^{*} \mathrm{~kg}^{-1}$ d.w. $[6,8,9,12]$. By the results of our research, Calcium content in the Birch leaves is within this range, while in the leaves of Black locust and Maple the examined value is above this limit. The analysis of scientific literature shows, Magnesium contain in the plants is $1000-3200 \mathrm{mg}^{*} \mathrm{~kg}^{-1}$ d.w. $[6,8,9,12]$. At a control site, the Magnesium concentrations in the leaves of all of three tree species slightly exceeded the values of the range pointed above.

The average concentrations of Phosphorus in plants are $1750-2300 \mathrm{mg}^{*} \mathrm{~kg}^{-1}$ d.w. [6, 8, 9, 20]. Phosphorus content in the leaves of all of tree's species at control site is below the values of this range. According to the scientific literature $[6,8,20]$, the average Sulfur content is from 7500 to $14000 \mathrm{mg}^{*} \mathrm{~kg}^{-1} \mathrm{~d}$.w. We found that in control territories the Sulfur concentrations in the leaves of all the trees were below the values of this range (Table 1).

Thus, the Calcium and Magnesium content in the leaves of trees from a control site is within the average values established for all the vegetation. In our opinion, this phenomenon may be due to the regional biogeochemical features of Kryvyi Rih iron-ore \& metallurgical district. As it is well known, in this region, the increased content of these macronutrients was detected in all the objects of Nature: soil, groundwater and surface water.

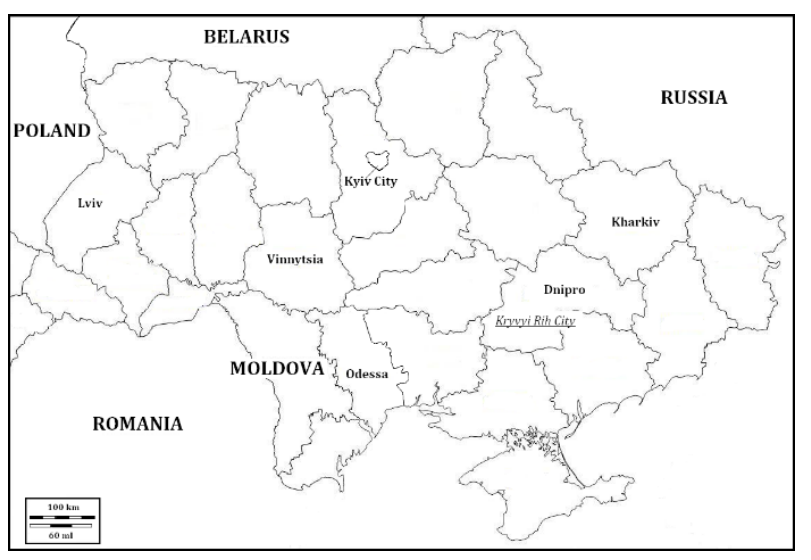

Ukraine

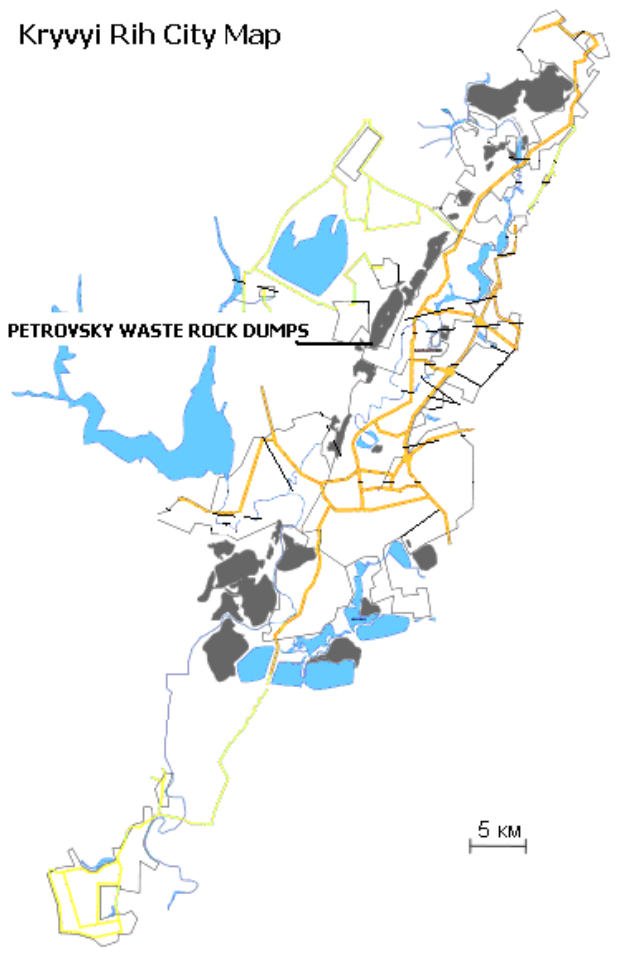

Kryvyi Rih

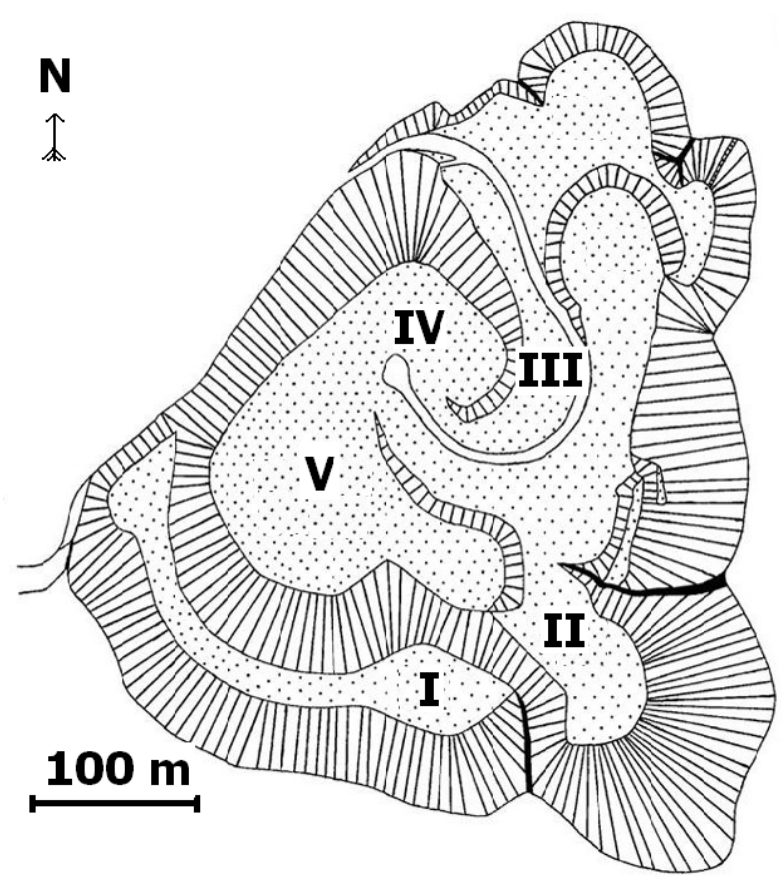

Petrovsky Waste Rock Dumps Map

Fig. 1. Location of study areas (I, II, III, IV, V - Study Plots)

Phosphorus and Sulfur concentrations in the leaves of trees from a control site were below the range values of these elements in all vegetation. This consistent pattern can be explained by the seasonal dynamics of nutrients concentration in the leaves of trees.

Average Ferrum content in all vegetation is $200 \mathrm{mg}^{*} \mathrm{~kg}^{-1}$ d.w., while in the leaves of trees that have grown outside by influence of industrial enterprises this metal content is $150-350 \mathrm{mg}^{*} \mathrm{~kg}^{-1}$ d.w. [2, 9, 12]. At a control site the Ferrum content was found at the same 
interval in the leaves of Birch and Black locust. Whereas, in the leaves of Maple a Ferrum concentration was slightly higher than this interval values (Table 2).

Table 1. Macronutrients content in the leaves of trees from a control site.

\begin{tabular}{|l|c|c|c|}
\hline \multirow{3}{*}{ Species of trees } & \multicolumn{1}{|c|}{$\begin{array}{c}\text { Aacronutrients content, } \\
\text { mg* kg-1 of dry weight }\end{array}$} \\
\cline { 2 - 4 } & M & & CV\% \\
\hline \multicolumn{4}{|c|}{ Potassium } \\
\hline Ash-leaved maple & 10110 & 192,09 & 28,46 \\
\hline Silver birch & 4633 & 184,00 & 21,41 \\
\hline Black locust & 4287 & 98,60 & 18,52 \\
\hline \multicolumn{4}{|c|}{ Calcium } \\
\hline Ash-leaved maple & 17610 & 1232,70 & 29,41 \\
\hline Silver birch & 13830 & 1244,70 & 22,29 \\
\hline Black locust & 19240 & 1539,20 & 25,47 \\
\hline \multicolumn{4}{|c|}{ Magnesium } \\
\hline Ash-leaved maple & 3589 & 260,20 & 29,12 \\
\hline Silver birch & 2780 & 201,69 & 31,22 \\
\hline Black locust & 3276 & 230,01 & 21,78 \\
\hline \multicolumn{4}{|c|}{ Shosphorus } \\
\hline Ash-leaved maple & 939,10 & 79,93 & 35,41 \\
\hline Silver birch & 1065,00 & 86,48 & 38,45 \\
\hline Black locust & 1042,00 & 95,18 & 32,25 \\
\hline \multicolumn{4}{|c|}{} \\
\hline Ash-leaved maple & 846,00 & 68,61 & 29,54 \\
\hline Silver birch & 650,20 & 64,37 & 26,75 \\
\hline Black locust & 933,10 & 83,05 & 21,56 \\
\hline
\end{tabular}

$\mathrm{M}$ - arithmetic mean, $\mathrm{m}$ - standard error of mean, $\mathrm{CV} \%$ coefficient of variability.

Table 2. Heavy metals content in leaves of trees from the control site.

\begin{tabular}{|l|c|c|c|}
\hline \multirow{3}{*}{ Species of trees } & \multicolumn{1}{|c|}{$\begin{array}{c}\text { acronutrients content, } \\
\text { mg*kg-1 of dry weight }\end{array}$} \\
\cline { 2 - 4 } & M & m & CV\% \\
\hline \multicolumn{4}{|c|}{ Ferrum } \\
\hline Ash-leaved maple & 521,10 & 32,26 & 29,41 \\
\hline Silver birch & 301,70 & 21,79 & 26,89 \\
\hline Black locust & 304,10 & 12,86 & 21,85 \\
\hline \multicolumn{4}{|c|}{ Manganese } \\
\hline Ash-leaved maple & 87,16 & 4,97 & 24,63 \\
\hline Silver birch & 81,66 & 4,82 & 22,35 \\
\hline Black locust & 45,49 & 2,64 & 29,54 \\
\hline \multicolumn{4}{|c|}{ Zinc } \\
\hline Ash-leaved maple & 7,22 & 0,09 & 30,41 \\
\hline Silver birch & 44,55 & 1,86 & 32,85 \\
\hline Black locust & 9,50 & 0,20 & 31,45 \\
\hline \multicolumn{4}{|c|}{ Copper } \\
\hline Ash-leaved maple & 1,46 & 0,07 & 25,54 \\
\hline Silver birch & 2,35 & 0,15 & 29,56 \\
\hline Black locust & 1,38 & 0,05 & 28,75 \\
\hline \multicolumn{4}{|c|}{ Lead } \\
\hline Ash-leaved maple & 0,210 & 0,023 & 31,44 \\
\hline Silver birch & 0,165 & 0,018 & 36,85 \\
\hline Black locust & 0,129 & 0,014 & 35,78 \\
\hline \multicolumn{4}{|c|}{ Cadmium } \\
\hline Ash-leaved maple & 0,007 & 0,002 & 30,29 \\
\hline Silver birch & 0,031 & 0,006 & 31,77 \\
\hline Black locust & 0,003 & 0,001 & 32,45 \\
\hline
\end{tabular}

$\mathrm{M}$ - arithmetic mean, $\mathrm{m}$ - standard error of mean, CV\% coefficient of variability.
The average Manganese content in all vegetation is 200 mg*kg-1 d.w. $[9,12,20]$. We found that at a control site in the leaves of all tree species, the concentrations of this metal were well below than this range. Zinc concentrations in vegetation are around $30 \mathrm{mg} * \mathrm{~kg}-1 \mathrm{~d}$.w., and in the leaves of trees that have grown outside by industrial enterprises influence, they are at range 25-50 mg*kg-1 d.w. [8, 9, 12, 20]. According to our research, Zinc content in Birch leaves is within the same range. It should also be noted that the concentrations of this metal in the leaves of Black locust and Maple were significantly lower (Table 2).

In the Vegetation of the World, the average Copper contain is about $8 \mathrm{mg}^{*} \mathrm{~kg}^{-1} \mathrm{~d}$.w. $[9,12,20]$. We found that the concentrations of this metal in the leaves of all tree species were significantly below this level. Average Lead content in the vegetation is around $1,25 \mathrm{mg}^{*} \mathrm{~kg}^{-1} \mathrm{~d}$.w. [9, $12]$, and in the leaves of trees it is at the level of $0,5-1,0$ $\mathrm{mg}^{*} \mathrm{~kg}^{-1}$ d.w. $[12,20]$. The analysis of obtained results shows that at a control site the concentrations of this metal in the leaves of all the investigated tree species were below these values (Table 2)

The similar consistent patterns were found for Cadmium concentrations. In all the vegetation its content is $0,03-0,05 \mathrm{mg}^{*} \mathrm{~kg}^{-1}$ d.w. At a control site, the concentrations of this metal in the leaves of all the tree species were below these values (Table 2).

Thus, at a control site in the leaves of the trees, the only Ferrum and partially Zinc concentrations lie within the range of average values established for the vegetation. While, the concentrations of other metals (Manganese, Copper, Lead and Cadmium) are 2-7 times lower than the average values. In our opinion, this phenomenon can be explained by the effect of regional geochemical and biogeochemical anomaly, which is characterized by the increased content of Ferrum and Zinc. In addition, we believe that casual autumn dynamics of chemical elements in plants has the effect on the concentration of heavy metals in the leaves of trees.

\subsection{Macronutrients and heavy metals content in leaves at a devastated lands}

In the devastated lands at Kryvyi Rih iron-ore \& metallurgical district, the content of Potassium in the leaves of the trees is less than control values (Fig. 2).

We found that, in the leaves of trees from the devastated lands at Kryvyi Rih region Potassium concentrations were less than the control values in Maple - by $15-70 \%(p<0,05)$, in Birch - by $15-55 \%$ $(p<0,05)$. In the leaves of Black locust, both potassium content reduction (plots II III - by $10-45 \%(p<0,05)$ less) and accumulation of this element (plots IV - by $20 \%$ $(p<0,05)$ higher) were detected.

Calcium content in the leaves emerged below than control values too (Fig. 2): in Birch - by $19-54 \%$ $(p<0,05)$ and in Black locust - by $51-62 \%(p<0,05)$. It should be noted that the concentrations of this metal in Maple's leaves at the plots II, IV, V were at the level of control values, while at the plot III they were by $40 \%$ $(p<0,05)$ less than the control values (Fig. 2). 


\section{Potassium}

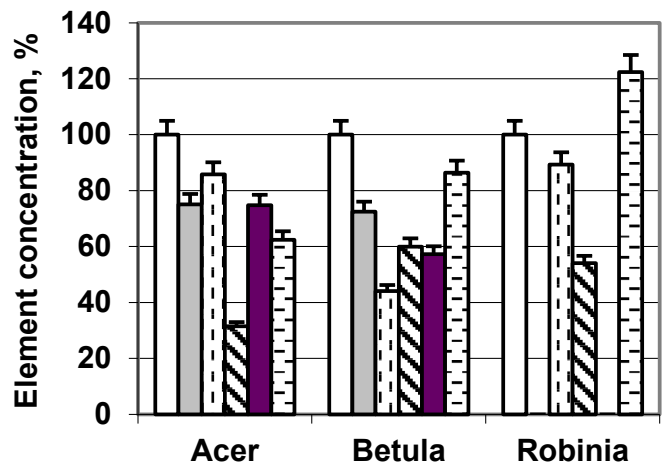

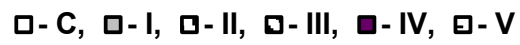

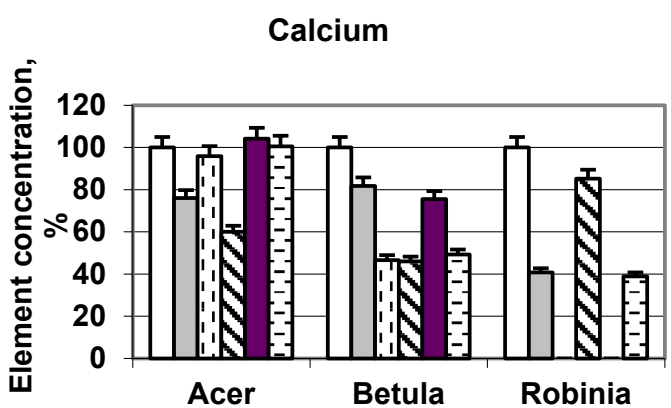

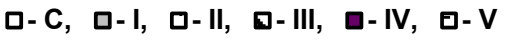

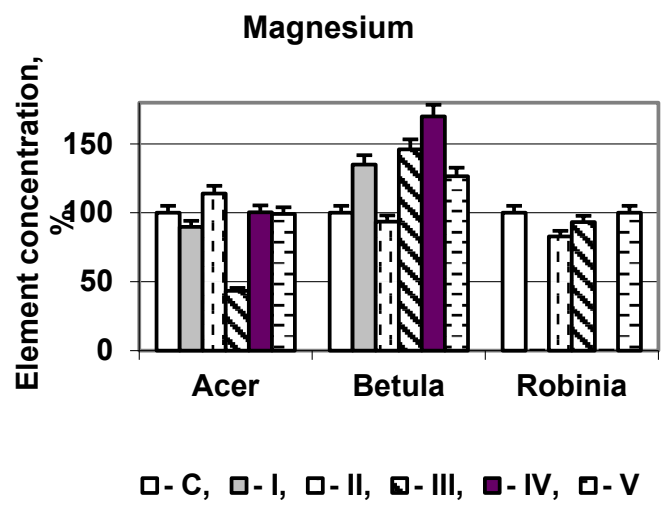

Fig. 2. The relative $\mathrm{K}, \mathrm{Ca}, \mathrm{Mg}$ content in the leaves of trees from the devastated lands at Kryvyi Rih district. The element content in the control is $100 \%$. Research areas: $\mathrm{C}$ - control, I, II, III, IV, V plots on devastated land. Acer - Ash-leaved maple, Betula - Silver Birch, Robinia - Black locust.

The analysis of obtained results (Fig. 2) shows that the Magnesium content was both higher and lower than the control values. Thus, in the leaves of Birch the accumulation of this element is predominant, the excess of control values is by $25-70 \%(p<0,05)$. In Maple's leaves, Magnesium concentrations at plot II were by $14 \%$ $(p<0,05)$ above control and at plots I and III they were $10-55 \%(p<0,05)$ less than control values. The content of this element in Black locust's leaves was within the control values (plots II and V) or by $17 \%(p<0,05)$ less (plot II).

\section{Phosphorus}

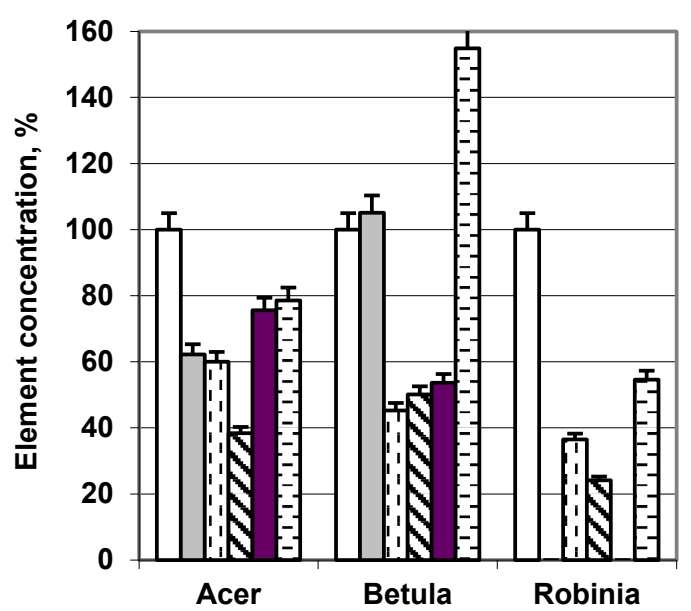

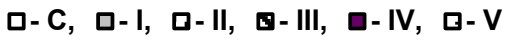

Sulfur

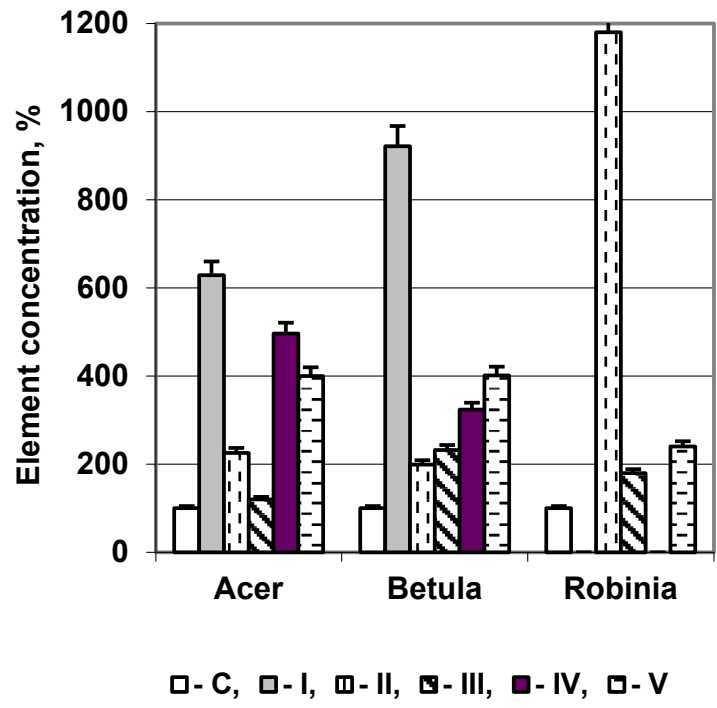

Fig. 3. The relative $\mathrm{P}$ и $\mathrm{S}$ content in the leaves of trees from the devastated lands at Kryvyi Rih district. The element content in the control is $100 \%$. Research areas: C - control, I, II, III, IV, V plots on devastated land. Acer - Ash-leaved maple, Betula Silver Birch, Robinia - Black locust.

It was found that the Phosphorus content in the leaves of trees from devastated lands at the Kryvyi Rih region was less than control values (Fig. 3): by $21-61 \%$ $(p<0,05)$ for Maple and by $46-63 \%(p<0,05)$ for Black locust. The content of this element in the Birch's leaves in most cases (plots II, II, IV) was below the control values by $44-54 \%(p<0,05)$, but at the plot $\mathrm{V}$ it emerged by $55 \%$ $(p<0,05)$ higher than the control value.

The analysis of obtained results shows that in the leaves of trees from the devastated lands at Kryvyi Rih region only accumulation of Ferrum is statistically significant (Fig. 4). Thus, the concentrations of this metal in the leaves were higher than the control values: in Black locust by 1,7-2,4 times $(p<0,05)$, in Birch by $1,9-4,0$ times $(p<0,05)$, in Maple by 1,2-5,0 times $(p<0,05)$. 
Manganese content exceeds the control values in Black locust leaves (by 2,7-8,1 times $(p<0,05))$ and in Birch (by 13-49 times $(p<0,05))$. While, in the Maple leaves, both accumulation of this metal (at plots I and II by 1,5-1,7 times above the control $(p<0,05))$ and its "leaching" (at plots III and IV by $15-19 \%$ below control $(p<0,05))$ were found.
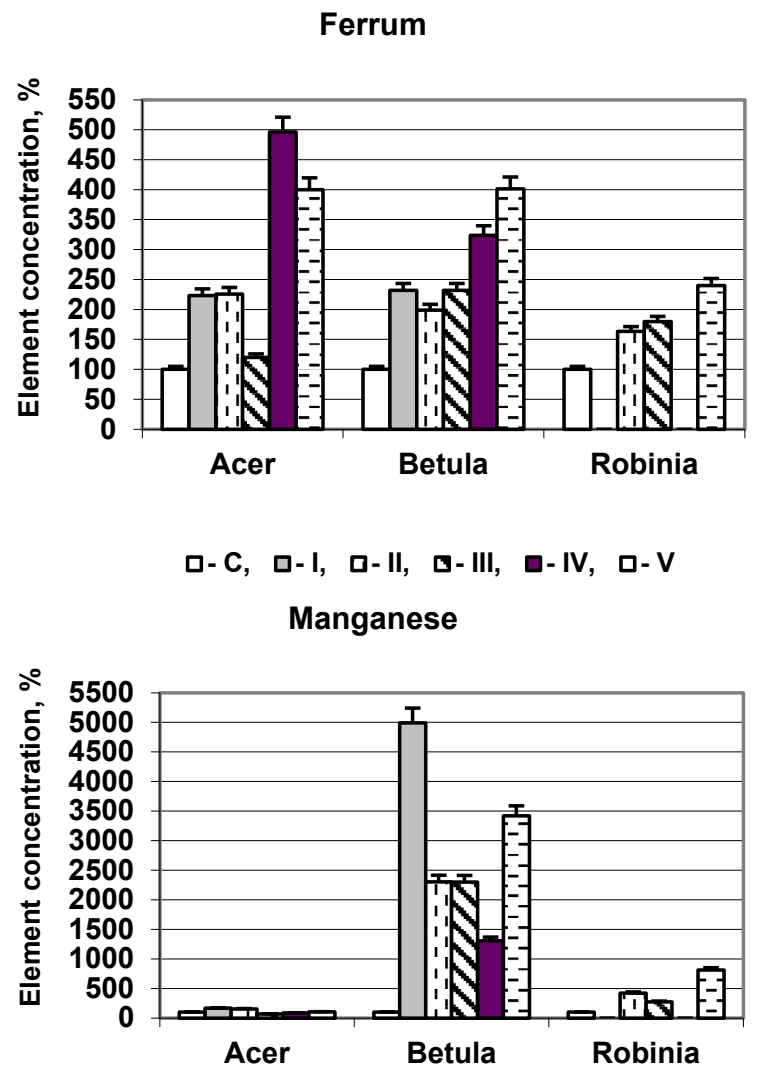

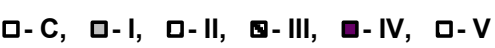

Zinc

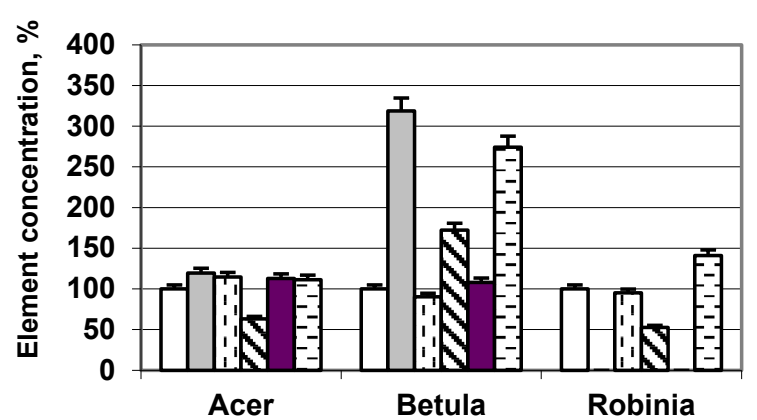

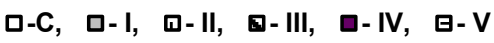

In most cases, the Zinc contents in the leaves of trees were higher than the control values: by $11-19 \%(p<0,05)$ in Maple, by 1,4 times $(p<0,05)$, in Black locust and 1,73.2 times $(p<0,05)$ in Birch. It was also found that at plot III concentrations of this metal were below the control values: in Maple by $37 \%(p<0,05)$ and in Black locust by $48 \%(p<0,05)$.
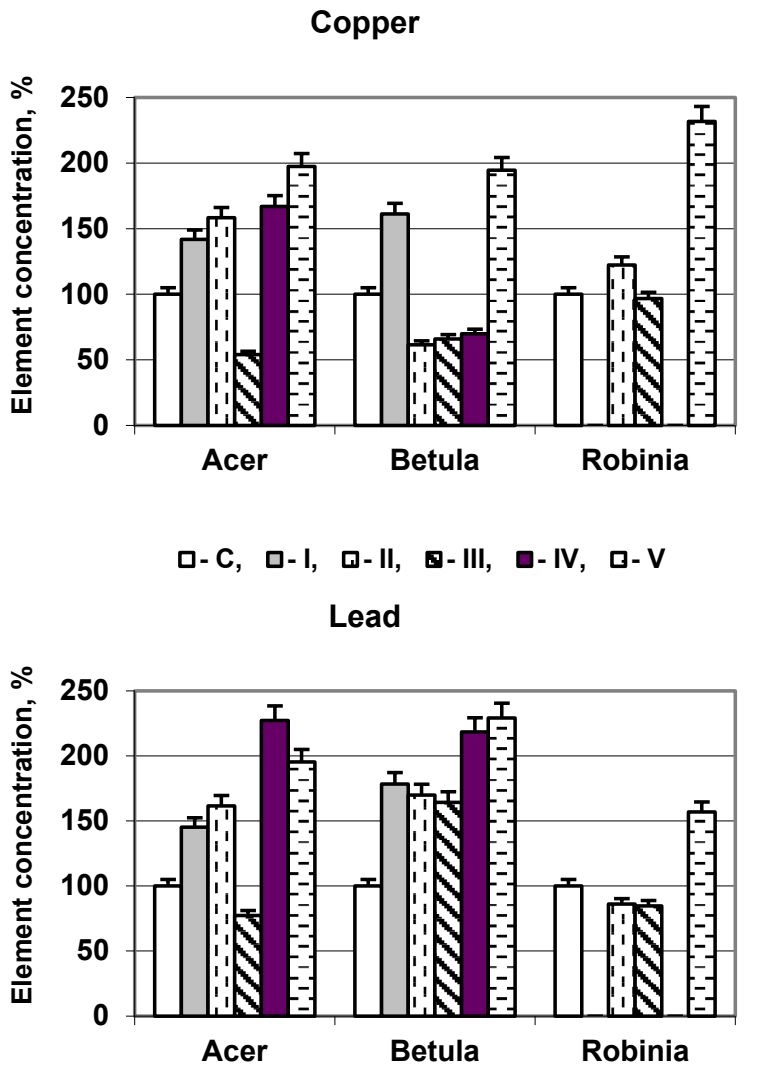

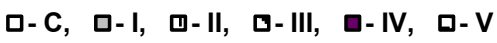

Cadmium

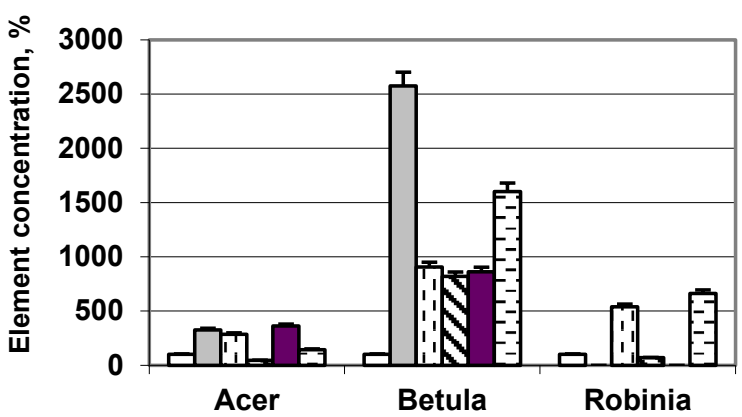

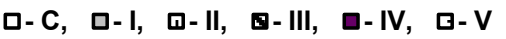

Fig. 4. The relative heavy metals content in the leaves of trees from the devastated lands at Kryvyi Rih district. The element content in the control is $100 \%$. Research areas: C - control, I, II, III, IV, V plots on devastated land. Acer - Ash-leaved maple, Betula Silver Birch, Robinia - Black locust.

It is established that only Copper accumulation was statistically significant in the leaves of Black locust. The concentration of this metal was by $1,2-2,3$ times $(p<0,05)$ above the control values. In the leaves of other tree species both high and low Copper content were detected. Thus, the concentrations of this metal exceed the control values: by 1,4-2,0 times $(p<0,05)$ at plots I, II, III and V in Maple, by 16,9 times $(p<0,05)$ at plots I and V in Birch. At the same time, the Copper content in the leaves was lower than the control values: by $46 \%$ 
$(p<0,05)$ at plots III in Maple, by $31-39 \%$ at plots III and IV in Birch.

Our findings (Fig. 4) show that Lead concentrations in Birch leaves at all the plots were higher than the control values by $1,6-2,3$ times $(p<0,05)$. In Maple leaves at plots I, II, IV and V this metal's concentrations were also higher than control values, by 1,5-2,3 $(p<0,05)$. But at plot III the Lead content was below than control by $23 \%$ $(p<0,05)$.

In Black locust leaves, this metal accumulation was detected only at plot $\mathrm{V}$, where its content was 1,6 times higher than control $(p<0,05)$. At the same time at plots III and IV, the Led concentrations were below than control values by $14-16 \%(p<0,05)$.

Cadmium content in the leaves of woody plants exceed the control values: by $9-25$ times $(p<0,05)$ in Birch, by 5,4-6,6 times $(p<0,05)$ in Black locust and by 5,4-6,6 times $(p<0,05)$ in Maple. It should also be noted that at plots III, the concentration of this metal is below the control values in the leaves of Maple and Black locust a, respectively by $32 \%$ and $45 \%(p<0,05)$.

\section{Discussions}

All macronutrients that we have studied $(\mathrm{K}, \mathrm{Ca}, \mathrm{Mg}, \mathrm{P}$, and $\mathrm{S}$ ) are biologically significant chemical elements. Therefore, these elements have a significant influence on all the important processes of life, growth and development of woody plant species $[5,12,15]$. In the course of evolution, for each chemical element, a certain interval of optimum was formed. The information about this interval is very important for the biological evaluation of the element content $[8,9]$.

According to scientific publications, the optimal Potassium concentration in plants is from 10000 to $14000 \mathrm{mg}^{*} \mathrm{~kg}^{-1} \mathrm{~d}$.w., while the content of this element exceeding $25000 \mathrm{mg}^{*} \mathrm{~kg}^{-1}$ d.w. is considered as phytotoxic $[6,8,9,20]$. According to the results of our research, at a control site in the leaves of Black locust and Birch, the Potassium concentration was below the biological optimum (4 200-4 $700 \mathrm{mg}^{*} \mathrm{~kg}^{-1}$ d.w.). The content of this metal in the leaves of Ash-leaved maple was slightly higher (about $10000 \mathrm{mg}^{*} \mathrm{~kg}^{-1} \mathrm{~d} . \mathrm{w}$.), but it was at the lower level of biological optimum.

On devastated lands at Kryvyi Rih iron-ore \& metallurgical district, the Potassium concentration ranges from 200 to $870 \mathrm{mg}^{*} \mathrm{~kg}^{1} \mathrm{~d}$.w., which is much less than the values of biological optimum. This is undoubtedly indicative of a deficiency of Potassium content for these plants.

The average optimal Calcium concentration in plants is between 10000 and $20000 \mathrm{mg}^{*} \mathrm{~kg}^{-1} \mathrm{~d} . \mathrm{w}$., and its phytotoxic amount is over $40000 \mathrm{mg}^{*} \mathrm{~kg}^{-1} \mathrm{~d}$.w. [6, 8, 9, $20]$. At the control site, the concentration of this element was within the biological optimum. On devastated lands, the growth and development of woody plants occur with some deficiency of this macroelement. The Calcium concentration in Birch leaves is 6 400-11300 mg* $\mathrm{kg}^{-1}$ d.w., in Black locust leaves is $7800-16400 \mathrm{mg}^{*} \mathrm{~kg}^{-1} \mathrm{~d}$.w.

The average Magnesium concentration in plants actually coincides with the range of biological optimum
(1 000-3 $200 \quad \mathrm{mg}^{*} \mathrm{~kg}^{-1}$ d.w.), and the phytotoxic concentration is more than $5500 \mathrm{mg}^{*} \mathrm{~kg}^{-1}$ d.w. $[6,8,9$, 20]. According to the results of our studies, the content of this metal in the leaves of trees at the control site is near the upper limit of the biological optimum (2 800-3 600 mg* $\mathrm{kg}^{-1}$ d.w.), but does not exceed the threshold of its phytotoxicity. On devastated lands, the Magnesium concentration in the leaves of trees in most cases was above the upper limit of the biological optimum (3 $200 \mathrm{mg}^{*} \mathrm{~kg}^{-1} \mathrm{~d}$.w.) but was below the phytotoxicity threshold (5 $500 \mathrm{mg}^{*} \mathrm{~kg}-1 \mathrm{~d} . \mathrm{w}$.).

According to scientific publications, the optimal Phosphorus concentration in plants is $1000-3000 \mathrm{mg}^{*} \mathrm{~kg}^{-}$ 1 d.w., the content of this element greater than 5,000 mg*kg-1 d.w. is considered as phytotoxic [6, 8, 920$]$. We found that at the control site the Phosphorus, content in the leaves of trees was at the minimum level of its biological optimum 950-1500 $\mathrm{mg}^{*} \mathrm{~kg}^{-1} \quad$ d.w. On devastated lands, in most cases, its concentration was much lower than the values of the biological optimum $350-750 \mathrm{mg}^{*} \mathrm{~kg}^{-1} \mathrm{~d}$.w. This fact indicates a deficit of this macronutrient.

The range of biological optimum for Sulfur content in plants is $1500-2500 \mathrm{mg}^{*} \mathrm{~kg}^{-1} \mathrm{~d} . \mathrm{w}$. and the phytotoxicity threshold is greater than $5000 \mathrm{mg}^{*} \mathrm{~kg}^{-1}$ d.w. and $[6,8,9$ $20]$. We found that at a control site in the leaves of trees, the Sulfur content was below the values of the biological optimum (650-950 mg* $\mathrm{kg}^{-1} \mathrm{~d} . \mathrm{w}$.). On devastated lands, in all cases, the Sulfur concentration in the leaves of trees was higher than control. However, the content of this element, with rare exceptions (Black locust at plot II), was in the range of biological optimum and did not exceed the phytotoxicity threshold.

According to the scientific literature [3, 12, 13, 27], $100-250 \mathrm{mg}^{*} \mathrm{~kg}^{-1} \mathrm{~d}$.w. Ferrum concentration in plants is considered optimal, and the phytotoxicity threshold is $500-550 \mathrm{mg}^{*} \mathrm{~kg}^{-1}$ d.w. We find that woody plants in all study areas contain extremely high concentrations of Ferrum in leaves: $300-500 \mathrm{mg}^{*} \mathrm{~kg}^{-1} \mathrm{~d} . \mathrm{w}$ at a control site and $650-2010 \mathrm{mg}^{*} \mathrm{~kg}^{-1} \mathrm{~d} . \mathrm{w}$ at devastated lands. Therefore, it can be assumed that woody plants are clearly exposed to the phototoxic effects of high concentrations of this metal.

Manganese content in plants from 50 to $200 \mathrm{mg}^{*} \mathrm{~kg}^{-1}$ d.w. considers as optimal, and if metal content is more than $300-400 \mathrm{mg}^{*} \mathrm{~kg}^{-1} \mathrm{~d}$.w. a stable phytotoxic effect was observed [3, 10, 12, 29]. We found that at a control site a Manganese concentrations in the leaves of trees for all species was in the optimality range $-50-90 \mathrm{mg}^{*} \mathrm{~kg}^{-1} \mathrm{~d}$.w. On devastated lands, the content of this metal in the Maple's leaves was slightly higher than the control values (70-170 mg* $\mathrm{kg}^{-1}$ d.w.), but does not go beyond the optimum. While, the Manganese concentrations in Black locust's leaves and in Birch's leaves significantly exceed the toxicity threshold (300-800 and $2300-5000 \mathrm{mg}^{*} \mathrm{~kg}^{-1}$ d.w., respectively). Hence, the plants are influenced by Manganese phytotoxicity.

For Zinc, the optimum range of its content in plants is $10-50 \mathrm{mg}^{*} \mathrm{~kg}^{-1} \mathrm{~d}$.w. and its phytotoxicity threshold is 100 mg* $\mathrm{kg}^{-1}$ d.w. [10, 12, 26, 30]. According to our studies results, the concentrations of this metal in the leaves of Maple and Black locust were in the optimum range (both 
at the control site and on the devastated lands (except for plot V)). In Birch leaves, Zinc concentrations reach 100280 mg* $\mathrm{kg}^{-1}$ d.w., which actually exceeds the phytotoxicity threshold.

Data from scientific publications indicate that Copper concentrations in plants of $5-10 \mathrm{mg}^{*} \mathrm{~kg}^{-1} \mathrm{~d}$.w. are maintained optimal, and the phytotoxical threshold is greater than $20 \mathrm{mg}^{*} \mathrm{~kg}^{-1} \mathrm{~d} . \mathrm{w}$. [3, 11, 25, 26]. The results of our studies have shown that the concentrations of this metal in the leaves of all three tree species do not exceed the lower threshold of the optimum zone: at a control site $-1,4-2,4 \mathrm{mg}^{*} \mathrm{~kg}^{-1} \mathrm{~d}$.w. and at devastated lands - 0,8-4,6 $\mathrm{mg}^{*} \mathrm{~kg}^{-1} \mathrm{~d}$.w. Therefore, we can assume that there is a deficiency of this important trace element.

The biological optimum range for Lead concentration in plants is $5-10 \mathrm{mg}^{*} \mathrm{~kg}^{-1} \mathrm{~d} . \mathrm{w}$. , and the phytotoxical threshold is $30 \mathrm{mg}^{*} \mathrm{~kg}^{-1}$ d.w. [4, 11, 13, 20]. We have found that the content of this metal in the leaves of trees does not exceed the minimum value of the biological optimum: $0,13-0,21 \mathrm{mg}^{*} \mathrm{~kg}^{-1} \mathrm{~d} . \mathrm{w}$. at the control site and $0,1-0,48 \mathrm{mg}^{*} \mathrm{~kg}^{-1} \mathrm{~d} . \mathrm{w}$. at devastated lands.

According to scientific publications, the optimal Cadmium concentration in plants is $0,005-0,020 \mathrm{mg}^{*} \mathrm{~kg}^{-1}$ d.w., the content of this element greater than 0,200 $\mathrm{mg}^{*} \mathrm{~kg}^{-1} \mathrm{~d}$.w. is considered as phytotoxic $[3,10,25,28]$. We found that at a control site, the content of this metal in the leaves of all three species was within the optimum range: $0,0029-0,0306 \mathrm{mg}^{*} \mathrm{~kg}^{-1} \mathrm{~d} . \mathrm{w}$. At devastated lands, Cadmium concentration was also in the optimum range for Maple $\left(0,0103-0,0234 \mathrm{mg}^{*} \mathrm{~kg}^{-1}\right.$ d.w.) and for Black locust $\left(0,0029-0,0200 \mathrm{mg}^{*} \mathrm{~kg}^{-1} \mathrm{~d} . w.\right)$. For Birch leaves, the content of this metal in all cases exceeds the values of the phytotoxicity threshold $0,2508-0,4897 \mathrm{mg}^{*} \mathrm{~kg}^{-1} \mathrm{~d}$.w.

Among the woody plants species that we have investigated, the maximum concentrations of macronutrients have been identified in Black locust and Ash-leaved maple. The maximum concentrations of heavy metals were found in the Silver birch.

\section{Conclusions}

Macronutrient (K, Ca, Mg, P, S) and heavy metals (Fe, $\mathrm{Mn}, \mathrm{Zn}, \mathrm{Cu}, \mathrm{Pb}, \mathrm{Cd}$ ) contents in leaves of three tree species indicate a difficult ecological conditions on the Petrovsky waste rock dump devastated lands at the Kryvyi Rih iron-ore \& metallurgical district. The growth and development of trees on these devastated lands is carried out with a clear nutrient's shortage (especially K and P) and metal's excess (especially Fe, Mn and $\mathrm{Zn}$ ).

Taking into account the revealed values of macronutrients optimal concentrations and revealed the heavy metals lowest content in the leaves, we assume that Ash-leaved maple Acer negundo and Black locust Robinia pseudoacacia (compared to the Silver Birch Betula pendula) are more resistant to the geochemical conditions of devastated lands. Therefore, species of trees can be recommended for the creation of artificial tree plantations on devastated lands.

The authors are grateful to the to the DAAD program "Scientific Cooperation with Universities in Developing Countries" for the opportunity to perform analytical work at the Institute of
Biosciences Laboratory, Freiberg University of Technology and Mining Academy (Freiberg, Germany).

\section{References}

1. M.B. Adams (ed.), The forestry reclamation approach: guide to successful reforestation of mined lands (U.S. Department of Agriculture, Forest Service, Northern Research Station, 2017). doi:10.2737/NRS GTR-169.

2. A.M.O. Ajasa, M.O. Bello, A.O. Ibrahim, I.A. Ogunwande, N.O. Olawore, Heavy trace metals and macronutrients status in herbal plants of Nigeria. Food Chem. 85(1), 67-71 (2004). doi:10.1016/j.foodchem.2003.06.004

3. H. Ali, E. Khan, M.A. Sajad, Phytoremediation of heavy metals - concepts and applications. Chemosphere 91, 869-881 (2013). doi:10.1016/j.chemosphere.2013.01.075

4. S. Amanifar, N. Aliasgharzad, M. Toorchi, M. Zarei, Lead phytotoxicity on some plant growth parameters and proline accumulation in mycorrhizal tomato (Lycopersicon esculentum L.). Int. J. Biosci. 4(10), 80-88 (2014). doi:10.12692/ijb/4.10.80-88

5. A.V. Barker, D.J. Pilbeam, Handbook of plant nutrition (Taylor \& Francis Group, Boca Raton, 2010)

6. V.N. Bashkin, N.S. Kasimov, Biogeochemistry (Scientific World, Moscow, 2004)

7. Yu.V. Bielyk, V.M. Savosko, Yu.V. Lykholat, Taxonomic composition and synanthropic characteristic of woody plant community on Petrovsky waste rock dumps (Kryvorizhzhya). Ecological Bulletin of Kryvyi Rih District 4, 104-113 (2019). doi:10.31812/eco-bulletin-krd.v4i0.2565

8. Yu.M. Dmytruk, M.A. Berbets, Fundamentals of Biogeochemistry (Book-XXI, Chernivtsi, 2009)

9. V.V. Dobrovolskiy, Fundamentals of Biogeochemistry (Academy, Moscow, 2003)

10. A. Emamverdian, Y. Ding, F. Mokhberdoran, Y. Xie, Heavy Metal Stress and Some Mechanisms of Plant Defense Response. Sci. World J. 2015, 1-18 (2015). doi:10.1155/2015/756120

11. D. Gjorgieva-Ackova, Heavy metals and their general toxicity for plants. Plant Sci. Today 5(1), 1418 (2018). doi: 10.14719/pst.2018.5.1.355

12. A. Kabata-Pendias, Trace elements in soils and plants (Taylor and Francis Group, Boca Raton, 2011)

13. V. Katrin, How plants cope with heavy metals. Bot Stud. 55, 35 (2014). doi:10.1186/1999-3110-55-35

14. S. Kivinen, Sustainable post-mining land use: are closed metal mines abandoned or re-used space? $\begin{array}{llll}\text { Sustainability } & 9 & \end{array}$ doi:10.3390/su9101705

15. F.J.M. Maathuis, Physiological functions of mineral macronutrients. Curr. Opin. Plant Biol. 12, 250-258 (2009). doi:10.1016/j.pbi.2009.04.003 
16. S.E. Macdonald, S.M. Landhausser, J. Skousen, J. Franklin, J. Frouz, S. Hall, D. Jacobs, S. Quideau, Forest restoration following surface mining disturbance: challenges and solutions. New Forests 46, 703-732 (2015). doi:10.1007/s11056-015-95064

17. J.H. McDonald, Handbook of biolological statistics. (Sparky house publishing, Baltimore, 2014)

18. M. Pietrzykowski, Tree species selection and reaction to mine soil reconstructed at reforested post-mine sites: Central and eastern European experiences. Ecol. Eng. 3, $100012 \quad$ (2019). doi:10.1016/j.ecoena.2019.100012

19. V. Ranjan, P. Sen, D. Kumar, B. Singh, Reclamation and rehabilitation of waste dump by eco-restoration techniques at Thakurani iron ore mines in Odisha. Int. J. Miner. Process. 7(3), 253-264 (2016). doi:10.1504/IJMME.2016.078372

20. S.D. Rudyshyn, Fundamentals of Biogeochemistry (Academia, Kyiv, 2013)

21. V.M. Savosko, Yu.V. Lykholat, K.M. Domshyna, T.Y. Lykholat, Ecological and geological determination of trees and shrubs' dispersal on the devastated lands at Kryvorizhya. Journal of Geology, Geography and Geoecology 27(1), 116-130 (2018). doi: $10.15421 / 111837$

22. V.M. Savosko, Yu.V. Lykholat, Yu.V. Bielyk, T.Y. Lykholat, Ecological and geological determination of the initial pedogenesis on devastated lands in the Kryvyi Rih Iron Mining \& Metallurgical District (Ukraine). Journal of Geology, Geography and Geoecology 28(4), 738-746 (2019). doi: $10.15421 / 111969$

23. J. Skousen, C.E. Zipper, Post-mining policies and practices in the Eastern USA coal region. International journal of coal science \& technology 1(2), 135-151 (2014). doi:10.1007/s40789-0140021-6

24. D.K. Tripathi, V.P. Singh, D.K. Chauhan, S.M. Prasad, N.K. Dubey, Role of macronutrients in plant growth and acclimation: recent advances and future prospective, in Improvement of crops in the era of climatic changes, ed by. P. Ahmad et al., vol 2 (Springer, New York, 2014), pp. 197-216. doi:10.1007/978-1-4614-8824-8 8

25. L. Versieren, S. Evers, H. Abd Elgawag, H. Asard, E. Smolders, Mixture toxicity of copper, cadmium, and zinc to barley seedlings is not explained by antioxidant and oxidative stress biomarkers. Environ Toxicol Chem. 36, 220-230 (2017). doi:10.1002/etc.3529

26. S. Yadav, Heavy metals toxicity in plants: an overview on the role of glutathione and phytochelatins. S. Afr. J. Bot. 76, 167-179 (2010). doi:10.1016/j.sajb.2009.10.007

27. F.K. Zengin, O. Munzuroglu, Effects of some heavymetals on content of chlorophyll, proline and some antioxidant chemicals in bean (Phaseolus vulgaris L.) seedlings. Acta Biol. Crac. Ser. Bot. 47(2), 157-164 (2005)

28. B. Zhou, W. Yao, S. Wang, X. Wang, T. Jiang, The metallothionein gene TaMT3 from Tamarix androssowii confers $\mathrm{Cd}^{2+}$ tolerance in Tobacco. Int. J. Mol. Sci. 15(6), 10398-10409 (2014). doi:10.3390/ijms 150610398

29. C.E. Zipper, J. Burger, J.G. Skousen, P.N. Angel, C.D. Barton, V. Davis, J. Franklin, Restoring forests and associated ecosystem services on appalachian coal surface mines. Environ. Management 47, 751765 (2011). doi:10.1007/s00267-011-9670-z

30. J. Zivkovic, S. Razic, J. Arsenijevic, Z. Maksimovi, Heavy metal contents in Veronica species and soil from mountainous areas in Serbia. J. Serb. Chem. Soc. 77(7), 959-970 (2012). doi:10.2298/JSC111225221Z

31. M. Zika, K.H. Erb, The global loss of net primary production resulting from human-induced soil degradation in drylands. Ecol. Econ. 69, 310-318 (2009). doi:10.1016/j.ecolecon.2009.06 